Original Research Paper

\title{
Production and Characterization of Exopolysaccharide from Novel Bacillus sp. M3 and Evaluation on Development Sub- Chronic Aluminum Toxicity Induced Alzheimer's Disease in Male Rats
}

\author{
${ }^{1}$ Mohsen M.S. Asker, ${ }^{2}$ Abeer Y. Ibrahim, ${ }^{1}$ Manal G. Mahmoud and ${ }^{1}$ Saher S. Mohamed \\ ${ }^{I}$ Department of Microbial Biotechnology, National Research Centre, 33 Bohouth St., Dokki, Giza, 12622, Egypt \\ ${ }^{2}$ Department of Medicinal and Aromatic Plants Researches, National Research Centre, 33 Bohouth St., Dokki, 12622, Egypt
}

Article history

Received: 14-03-2015

Revised: $15-04-2015$

Accepted: 06-05-2015

Corresponding Author: Mohsen M.S. Asker

Department of Microbial

Biotechnology, National

Research Centre, 33 Bohouth

St., Dokki, Giza, 12622, Egypt

Fax: +2 02333371931

Tel: +20233335982 or +2 0129552825

Email: mohsenmsa@yahoo.com, mohsenmsa@hotmail.com

\begin{abstract}
The number of patients suffering from Alzheimer's Disease (AD) all over the world is rising continually and becomes one of the biggest challenges for most societies throughout the world. The potential of peripheral biochemical markers as complementary tools in the neuronphsychiatric evaluation of these patients has claimed further attention. The aims of our study were to isolate the bacteria that able to produce exo-polysaccharides and to characterize then exopolysaccharide producing strains by $16 \mathrm{~S}$ rDNA sequencing method. The exopolysaccharide (MEPS) produced from a newly isolated Bacillus sp. $\mathrm{M} 3$ was obtained by ethanol precipitation $\left(6.5 \mathrm{~g} \mathrm{~L}^{-1}\right.$ growth medium). The molecular masse of the MEPS was $1.45 \times 10^{4} \mathrm{~g} / \mathrm{mol}$ wherein FT-IR, UVVis spectral analyses revealed prevalence of characteristic primary belonged to $\alpha$-type exopolysaccharide with a pyran ring. Further, HPLC analysis revealed its two monosaccharide constituents galacturonic acid and glucuronic acid at molar ratio of 1:1. The second stage was the evaluation of anti-intoxicated effect of MEPS against aluminum chloride induced Alzheimer in rat relevant to its effect on oxidative stress, antioxidant brain status, cholinergic markers and serum level of S100B protein together with polysaccharide sub-chronic toxicity at $1 / 10 \mathrm{LD}_{50}$ in both $\mathrm{AD}$ and control experimental animal groups to find their diagnostic value in this disease. MEPS ameliorated antioxidant status and reduced all oxidative stress parameters in brain tissue with decreasing S100B as compared to aluminum toxicant group with significant acetyl cholinesterase inhibition which increase acetylcholine concentration in brain tissue. No toxicity was observed for MEPS in sub-chronic toxicity study for 90 days in all rat organs or liver and kidney function.
\end{abstract}

Keywords: Bacillus sp. M3, Exopolysaccharides, Oxidative Stress, Alzhei-mer's Disease

\section{Introduction}

Dysregulated activation of inflammation and oxidative stress has been recognized as one principal causes of inflammatory diseases such as rheumatoid arthritis, diabetes, Alzheimer's disease and even cancers (Balkwill and Mantovani, 2012; Schacter and Weitzman, 2002). Exopolysaccharides (EPSs) contribute to various physiological activations in human beings as antitumor, antiviral, anti-inflammatory agents, anticardiovacular disease and anti-neurodegenerative disease specific Alzheimer's disease (Calazans et al., 1997; Mahmoud et al., 2014).

Recently, major attention has been focused on polysaccharides from marine due their structural and functional diversity beside it is natural source compounds (Gutierrez et al., 2012). The novel active EPSs from marine bacteria hold a great potential 
application in biology and pharmacology such as antioxidant activity (Luo and Fang, 2008), immune stimulating effects (Xu et al., 2009), antitumor effects (Tong et al., 2009) and antiviral activity (Wang et al., 2007). Owing to the various functions of EPSs in marine ecosystem such as adhesion of bacteria, stabilization of biofilms and maintenance of symbiotic association with different species, investigation of EPSs producing marine bacteria was reviewed (Christensen et al., 1985; Decho, 1990; Holmstrom and Kjelleberg, 1999). The EPSs have many advantages, including non-toxic and safe, unique physical and chemical properties, simply separated from bacteria and can be produced at large scale (Czaczyk and Myszka, 2007). Alzheimer's Disease (AD) is a devastating neuron-degenerative disorder manifested by deterioration in memory and cognition, impairment in performing activities of daily living and many behavioral and neuro-psychiatric illnesses (Cummings, 2004). AD is the most common form of dementia in the old age. The percentage of persons with Alzheimer disease increases by a factor of two with every five years of age, so $1 \%$ of 60 year old and $30 \%$ of 85 year old have the Disease (Upadhyaya et al., 2010). S100B is a calcium binding protein that in the nervous system is mainly concentrated in glial cells. It has both trophic and potentially toxic effects on neurons and neuritis, suggesting that S100B over expression plays an important role in the genesis of neuritic changes in amyloid- $\beta$ plaques, in the progression of diffuse non-fibrillar amyloid deposits to neuritic forms and consequently in the progression of disease itself (Mark and Griffin, 2001). It is hypothesized that high concentrations of S100B act in the pathogenesis of neurodegenerative processes, possibly though oxidative stress mechanisms (Emanuele et al., 2011). Oxidative stress has been shown to be a prominent and early feature of vulnerable neurons in AD. Exposure to oxidative stress induces the accumulation of intracellular Reactive Oxygen Species (ROS), which in turn causes cell damage in the form of protein, lipid and DNA oxidations. Elevated ROS levels are associated with increased deposition of amyloid $\beta$ and formation of senile plaques, a hallmark of AD brain. If enhanced ROS exceeds the basal level of cellular protective mechanisms, oxidative damage and cell death will result. Hence, substances that can reduce oxidative stress are thought as possible drug candidates for treatment or preventive therapy of neurodegenerative diseases such as AD (Nelson et al., 2009). Our study aims to isolate, partially characterize the exopolysa-ccharide from a newly isolated Bacillus sp. M3 (MEPS) and to evaluate anti-Alzheimer effect of MEPS in intoxicated animals with aluminum chloride with investigation of its sub-chronic toxicity in intoxicant and normal animals.

\section{Materials and Methods}

\section{Isolation of Exopolysaccharides Producing Bacterial Strain}

Marine sediment samples (5 g) collected from mangrove (Alexandra, Egypt) were suspended in $95 \mathrm{~mL}$ sterile water. Serial dilutions of water samples were plated on marine nutrient agar plates. After incubation at $30^{\circ} \mathrm{C}$ for $72 \mathrm{~h}$, cultural logogriphic bacterial colony was obtained. Purification of single colonies was done by dilution streaking on marine nutrient agar plates. Single colony cultures were maintained on marine nutrient agar. Pure colonies of each facultative logographic isolates (capable of forming mucous and ropy colonies) were then inoculated into $50 \mathrm{~mL}$ of screening marine nutrient medium in $250-\mathrm{mL}$ Erlenmeyer flask, incubated at $37^{\circ} \mathrm{C}$ in a rotary shaker at $150 \mathrm{rpm}$ for $48 \mathrm{~h}$. After centrifugation at $5000 \mathrm{rpm}$ for $20 \mathrm{~min}$, the supernatant was mixed with three volumes of chilled ethanol. The precipitate was collected by centrifugation at $5000 \mathrm{rpm}$ for $20 \mathrm{~min}$ and the pellets were dried at $40^{\circ} \mathrm{C}$ under vacuum. EPS production was determined by quantifying the carbohydrate content of the pellets as glucose equivalents using the phenol-sulfuric acid method (Dubois et al., 1956).

\section{Strain Identification}

\section{Morphological and Biochemical Studies}

Morphological, physiological and biochemical characterization for the high EPS producing bacterium NRC27 were carried out. Characteristics of the isolate were compared with data from (Holt, 1986).

\section{Phylogenic Studies}

The identification was confirmed with phylogenic analysis. Genomic DNA from the NRC27 was isolated and quality was evaluated on $1.2 \%$ agarose gel, a single band of high Mw DNA has been observed. A Polymerase Chain Reaction was performed using ITS15'TCCGTAGGTGAACTTTGCGG3' and ITS45'TCCTCCGCTTATTGATATGC3' primers (Gardes and Bruns, 1993). A single discrete PCR amplicon band was observed when resolved on agarose gel. The PCR amplicon was purified to remove contaminants. Forward and reverse DNA sequencing reaction of PCR amplicon was carried and then performs 35 amplification cycles at $94^{\circ} \mathrm{C}$ or $45 \mathrm{sec}, 55^{\circ} \mathrm{C}$ for $60 \mathrm{sec}$ and $72^{\circ} \mathrm{C}$ for $60 \mathrm{sec}$. DNA fragments are amplified about $1,400 \mathrm{bp}$ in the case of bacteria. Include a positive control (E. coli genomic DNA) and a negative control in the PCR. Sequencing was performed by using Big Dye terminator cycle sequencing kit (Applied BioSystems, USA). Sequencing products were resolved on an Applied Bio-systems model 3730XL automated DNA sequencing system (Applied BioSystems, USA). Data were submitted to 
GenBank database. The DNA sequence was compared to the GenBank database in the national Center for Biotechnology Information (http: //www.ncbi.nlm.nih. gov) using the BLAST program (Tamura et al., 2011).

\section{Production and Isolation of Exopolysaccharide}

Inoculums was prepared by transferring one loop full of culture from marine nutrient slant to an $250 \mathrm{~mL}$ conical flask containing $50 \mathrm{~mL}$ seed medium consisting of $(\mathrm{g} / \mathrm{L})$ glucose 20 , yeast extract $0.1, \mathrm{CaCO}_{3} 1$, $\mathrm{NH}_{4} \mathrm{NO}_{3} 0.8, \mathrm{~K}_{2} \mathrm{HPO}_{4} 0.6, \mathrm{KH}_{2} \mathrm{PO}_{4} 0.5, \mathrm{MgSO}_{4} .7 \mathrm{H}_{2} \mathrm{O}$ $0.05, \mathrm{MnSO}_{4} \cdot 4 \mathrm{H}_{2} \mathrm{O} 0.1$ and dissolved in $75 \%$ seawater (Kim et al., 1998). The seed culture was grown at $37^{\circ} \mathrm{C}$ on a rotary shaker incubator at $150 \mathrm{rpm}$ for $18 \mathrm{~h}$. After incubation, $3 \mathrm{~mL}$ of the seed culture was transferred into a $250 \mathrm{~mL}$ Erlenmeyer flask containing $50 \mathrm{~mL}$ of fermentation medium consisting of $(\mathrm{g} / \mathrm{L})$ sucrose 20 , peptone 4, yeast extract 2 and dissolved in $75 \%$ seawater, $\mathrm{pH}$ 7.0. The fermentation cultures were then incubated at $37^{\circ} \mathrm{C}$ with shaking at $150 \mathrm{rpm}$ for 3 days. The EPS sample was prepared from strain NRC-27 culture in the fermentation medium. The fermented broth was collected and centrifuged at $5000 \mathrm{rpm}$ at $4{ }^{\circ} \mathrm{C}$ for 20 min. Trichloroacetic acid $(50 \mathrm{~g})$ was added to the 1000 $\mathrm{mL}$ supernatant, left overnight at $4^{\circ} \mathrm{C}$ and centrifuged at $5000 \mathrm{rpm}$. The $\mathrm{pH}$ of clear solution was adjusted to 7.0 with $0.1 \mathrm{M} \mathrm{NaOH}$ and dialyzed three times $(1000 \mathrm{~mL} \times 3)$ against flowing tap-water using dialysis tubing (MWCO 2000) for $24 \mathrm{~h}$. The deproteinated solution through precipitation with 1, 2, 3 and 4 volume chilled ethanol, the major fraction precipitate was collected and redissolved in distilled water, dialyzed with distilled water and precipitated by chilled absolute ethanol washed by acetone, diethyl ether and dried at $60^{\circ} \mathrm{C}$ until constant weight and coded MEPS (Asker et al., 2009).

\section{Analysis of Monosaccharide Composition}

For monosaccharide composition analysis, MEPS (200 mg) was hydrolyzed with $2 \mathrm{~mL}$ of formic acid at $100^{\circ} \mathrm{C}$ in a sealed tube for $5 \mathrm{~h}$. Excess acid was removed by flash evaporation on a water bath at a temperature of $40^{\circ} \mathrm{C}$ and co-distilled with water (1 $\mathrm{mL} \times 3$ ) (Sudhamani et al., 2004). The monosaccharides contents were quantified by HPLC on a Shimadzu ShimPack SCR-101N column $(7.9 \times 300 \mathrm{~mm})$ using deionized water as the mobile phase (flow rate $0.5 \mathrm{~mL} / \mathrm{min}$ ), as described by El-Sayed et al. (2005).

\section{Molecular Weight Determination}

The molecular weight of MEPS was determined on an Agilent 1100 HPLC system equipped with a Refractive Index Detector (RID) and FPl gel particle size $(5 \mu \mathrm{m}), 3$ columns of pore type $(100,104,105$ $\left.\mathrm{A}^{\circ}\right)$ on series, length $7.5 \times 300 \mathrm{~mm}(1000,5000000)$ for DMF solvent Styrogel HR-DMF, $3 \mu \mathrm{m}(7.8 \times 300 \mathrm{~mm})$,
Water Company Ireland. One column (5000-600000) for water solvent (polyethylene oxide/glycol standard) PL aquagel-OH $7.5 \mathrm{~mm}$ and $30 \mathrm{um}$ pore type $8 \mathrm{um}$ particle size. PL aquagel-OH $7.5 \mathrm{~mm}, 50 \mathrm{um}$ pore type, 8um particle size, in series $\mathrm{Mw}$ from 100$1250000 \mathrm{~g} \mathrm{moL}^{-1}$. The sample $0.01 \mathrm{~g}$ was dissolved in $2 \mathrm{~mL}$ of solvent and then it filtrated by siring filter 0.45 then the sample but in GPC device (Jun et al., 2009). The polydispersity index calculated from the $\mathrm{Mw} / \mathrm{Mn}$ ratio (You et al., 2013).

\section{Infrared Spectroscopy}

The Fourier-Transform Infrared (FTIR) spectrum of MEPS was measured on a Bucker scientific 500-IR Spectrophotometer. The MEPS was mixed with $\mathrm{KBr}$ powder, ground and pressed into a $1 \mathrm{~mm}$ pellets for FTIR measurements in the range of 400-4000 $\mathrm{cm}^{-1}$ (Ray, 2006).

\section{Biological Activity of MEPS}

\section{Acute Toxicity Study}

The acute toxicity test for the MEPS was carried out to evaluate any possible toxicity. Male albino mice $(\mathrm{n}=$ 8) were obtained from the Animal House of National Research Centre, Egypt. Mice were tested by administering MEPS at different doses in an oral route by increasing or decreasing the dose, according to the response of animal (Bruce, 1985). The dosing patron was $50,100,200,400,800,1600,2000$ and $2500 \mathrm{mg}$ $\mathrm{kg}^{-1}$ body weight. All groups were observed for any gross effect or mortality during $48 \mathrm{~h}$. Death of half of examined animals was observed at $2 \mathrm{~g} \mathrm{~kg}^{-1}$ body weight. This study was approved by Medical Research Ethics Committee, National Research Centre, Egypt, under registration no. 11015 .

\section{Experimental Design}

Adult male spargue dawely rats (150-180 g) were obtained from the Animal House of National Research Centre, Egypt. Rats were fed on standard diet and maintained under laboratory conditions, temperature controlled at $23 \pm 2{ }^{\circ} \mathrm{C}$, relative humidity $60 \pm 5 \%$ and light/dark cycles $(12 / 12 \mathrm{~h})$. Animal were housed in polypropylene cages, each cage was contained eight or seven rats adapted for one week before starting the experiment. Animals were divided into four groups each contained 15 rats and they were treated as follows:

Group I: $\quad$ Rats received $1 \mathrm{~mL}$ saline solution for 120 days in an oral route, control group for Alzheimer and sub-chronic toxicity experiments.

Group II: Rats received $\mathrm{ALCl}_{3}$ orally at $17 \mathrm{mg} \mathrm{kg}^{-1}$ body weight for 30 days, served as positive intoxicant control group (Krasovskii et al., 1979).

Group III: Rats received saline for 30 days and then received MEPS orally at $200 \mathrm{mg} \mathrm{kg}^{-1}$ body 
weight for 90 days, served as vehicle control group and as sub-chronic toxicity group.

Group IV: Rats received $\mathrm{ALCl}_{3}$ orally at $17 \mathrm{mg} \mathrm{kg}^{-1}$ body weight for 30 and then treated with MEPS (200 $\mathrm{mg} \mathrm{kg}^{-1}$ body weight) for 90 days.

At the end of experiment, rats fasted overnight and were subjected to anesthesia to facilitate collection of blood samples while whole brain of each rat was rapidly dissected and washed with isotonic saline and dried on filter paper. Brain of each rat was weighed and homogenized to give $10 \%(\mathrm{w} / \mathrm{v})$ homogenate in ice cold medium containing $50 \mathrm{mM}$ Tris- $\mathrm{HCl}$ and $300 \mathrm{mM}$ sucrose at $\mathrm{pH}, 7.4$. The homogenate was centrifuged at $4^{\circ} \mathrm{C}$. The supernatant was stored at $-80^{\circ} \mathrm{C}$ and were used in biochemical analyses including oxidative stress biomarker (nitric oxide concentration by method of Montgomery and Dymock (1961), hydrogen peroxide concentration, reduced glutathione concentration (Griffith, 1980) and malondialdehyde (MDA) concentration (Ohkawa et al., 1979), antioxidant biomarker (total antioxidant capacity according to Koracevic et al. (2001), Superoxide Dismutase activity (SOD) (Kakkar et al., 1984), Catalase Activity (CAT) (Beers and Sizer, 1952), cholinesterase biomarker (acetylcholine conce-ntration and cholinesterase activity, kits were purchased from Quimica Clinica Aplicada S.A.) and S100B in sera was estimated by Enzyme Linked Immunoassay (ELISA), the kit was derived from Dia Sorin, USA according to Gao et al. (1997). Brain total protein conc. was measured for calculation of enzyme specific activity (Sedlack and Lindsay, 1968). The assessments were done by ELISA reader (Dynatech laboratories MRW micro plate reader, 2CXB2445).

\section{Biochemical Assessment of Sub-Chronic Toxicity Study}

Blood samples were collected from the retro orbital plexus, centrifuged at $3000 \mathrm{rpm}$ for $10 \mathrm{~min}$ to separate sera. The liver enzymatic activity was determined according to the colorimetric method described by Hannig et al. (2009). Reduced glutathione concentration was measured spectrophotometrically at $405 \mathrm{~nm}$ by the method of Plancarte and Hernandez (2004), while protein concentration $\left(\mathrm{g} \mathrm{dL}^{-1}\right)$ was determined according to Okutucu et al. (2007). Total lipid concentration (mg $\mathrm{dL}^{-1}$ ) was estimate by method of Vatassery et al. (1981). In addition, kidney function was assessed by measuring creatinine concentration $\left(\mathrm{mg} \mathrm{dL}^{-1}\right)$ according to Demirovic et al. (2009), uric acid concentration (mg $\mathrm{dL}^{-1}$ ) by the method of Carolina et al. (2005) also urea concentration $\left(\mathrm{mmol} \mathrm{L} \mathrm{L}^{-1}\right)$ was estimated according to Yoneyame et al. (2001).

\section{Effect on Vital Organs}

At the termination of polysaccharide treatment on 90th day, vital organs (heart, lungs, liver, kidneys, spleen and testis, male sex organs, were harvested from sacrificed rats. These were carefully examined for gross lesions and weighed (Precisa digital weighing balance, Type 300-9213/E 125A, Switzerland). The weight of each organ was standardized to $100 \mathrm{~g}$ body weight of each animal.

\section{Hematological Assessment}

Blood samples were collected from rats into Ethylene Diamine-Tetra Acetate (EDTA) bottles after super- ficially anaesthetized. Collected samples were analyzed for determination of Packed Cell Volume (PCV) (Dacie and Lewis, 1975), Red Blood Cell (RBC) count, hemoglobin (Anonymous, 1965), total and differential White Blood Cell (WBC) count percentage using standard methods (Ghai, 1995).

\section{Statistical Analysis}

The results obtained were presented as mean \pm SD while analysis of variance was performed by one way ANOVA procedure (SPSS 09.05).

\section{Results and Discussion}

\section{Screening for Bacterial Strains Producer of Exopolysaccharides}

Marine bacteria have become ever more popular and novel sources of EPSs. Although many known marine bacteria can produce EPSs, few of the EPSs are of biotechnological importance, so the search of EPSS that might have innovative applications is still of potential interest (Llamas et al., 2010). The promising strain was selected based on the development of mucoid morphology because it was one of the fundamental screenings for isolation of EPS producing bacteria (Inmaculada et al., 2010; Parthiban et al., 2014). A total of thirteen bacterial isolates collected from various marine samples and exhibiting mucoidal morphology on marine agar media were inoculated into shake flasks containing $50 \mathrm{~mL}$ of fermentation broth medium. Marine bacterial isolates were screened for their capacity to produce EPS. The highest yield of EPS $\left(6.01 \mathrm{~g} \mathrm{~L}^{-1}\right.$ growth medium) was obtained by a marine bacterium isolated from a mangrove sample.

\section{Taxonomical Studies}

\section{Morphological Characterization}

Identification of bacterial isolate NRC27 was carried out according to a great variety of morphological, cultural, physiological and biochemical features. The 
isolate NRC27 had short rod shape and was Grampositive, aerobic, catalase and oxidase-positive. The bacterial diameter was ranged from 0.3 to 0.5 and 0.9 to $3 \mu \mathrm{m}$. The organism was able to grow over a range of $\mathrm{pH}$ (from 5.0 to 7.0). It grew at temperatures ranging from 25 to $50^{\circ} \mathrm{C}$ and the optimal temperature was $40^{\circ} \mathrm{C}$. It had the ability to utilize many carbohydrates as a sole carbon source including lactose, sucrose, glucose, fructose, glycerol (Table 1). It was sensitive to Cephalothin and Mecillinam. The identification was confirmed by molecular analyses based on 16S rDNA.

\section{Molecular Characterization}

A molecular technique was used to prove and further confirm the identification of the isolate NRC27 to the species level. The partial 16S rDNA sequence was determined and was compared to the GenBank databases in the National Center for Biotechnology Information (NCBI) (http://www.ncbi.nlm.nih.gov) using the BLASTN 2.2.6 program. This isolate was found belonging to the genus Bacillus sp. with $99 \%$ homology level as depicted in the phylogenetic tree analysis. The isolate was identified as Bacillus sp. M3 (Fig. 1). The sequence was submitted to GenBank in NCBI (http://www.ncbi.nlm.nih.gov/nuccore/JQ425073) with the accession number KP09417.

\section{Isolation and Chemical Structural of MEPS}

Many marine bacteria could produce EPSs, such as Paenibacillus polymyxa, Edwardsiella tarda and Alteromonas (Guo et al., 2010). EPS production from Bacillus sp. M3 reached a maximum of $6.5 \mathrm{~g}$ of crude product per liter of growth medium after 3 day. The main fraction MEPS was obtained after fractionation with ethanol precipitation from the crude exopolysaccharide. The MEPS was collected for further analysis of structure and biological activity. It appeared as a white powder, with a negative response to the Bradford test. The fact that no absorption was detected by the UV spectra at both 260 and $280 \mathrm{~nm}$ indicated the absence of nucleic acids and protein. The monosaccharide of MEPS hydrolysate was determined by HPLC, wherein galacturonic acid: Glucuronic acid was identified in the hydrolysate and their molar ratios were $1: 1$, respectively. FT-IR analysis showed a broadly stretched intense peak at around $3428 \mathrm{~cm}^{-1}$ characteristic of $\mathrm{COO}^{-}$and a weak $\mathrm{C}-\mathrm{H}$ band at around $2928 \mathrm{~cm}^{-1}$. The relatively strong absorption peak at $\mathrm{a} \sim 1646 \mathrm{~cm}^{-1}$ indicated the characteristic IR absorption of polysaccharides (Bremer and Geesey, 1991). The band at $343.53 \mathrm{~cm}^{-1}$ region was attributed to the stretching vibration of $\mathrm{O}-\mathrm{H}$ in the constituent sugar residues (Kanmani et al., 2011). The band at $2927.41 \mathrm{~cm}^{-1}$ was associated with the stretching vibration of $\mathrm{C}-\mathrm{H}$ in the sugar ring.
Table 1. Morphological, cultural and physiological characterristics of the bacterial isolate

\begin{tabular}{ll}
\hline Characteristics & Bacterial isolate \\
\hline Morphology & Gram-positive, short rods, non-spore forming \\
Motile & Non-motile \\
Cultural & Circular, smooth, mucous, white \\
Physiological & Aerobic, catalase positive, halophilic \\
\hline
\end{tabular}

The band at $1649.8 \mathrm{~cm}^{-1}$ was due to the stretching vibration of $\mathrm{C}=\mathrm{O}$ and $\mathrm{COO}^{-}$. The absorptions around $1456.69 \mathrm{~cm}^{-1}$ represented $\mathrm{CH}_{2}$ and $\mathrm{O}-\mathrm{H}$ bonding. The strong absorption at $1068.08 \mathrm{~cm}^{-1}$ was dominated by glycosidic linkage $v(\mathrm{C}-\mathrm{O}-\mathrm{C})$-stretching vibration (Sun et al., 1998). In addition, the band at $836.95 \mathrm{~cm}^{-1}$ indicated the $\alpha$-pyranose form of the glucosyl residue. Therefore, the IR analysis suggested that it was highly likely that the MEPS belonged to $\alpha$-type heteropolysaccharide with a pyran ring (Cheng et al., 2008). The weight-average (Mw) and number-average (Mn) molecular weights and polydispersity (Mw/Mn) of the MEPS was analyzed by GPC. The MEPS in the GPC chromatogram (Fig. 2) was widely dispersed molecules polydispersity index $(\mathrm{Mw} / \mathrm{Mn}=2.5$, the ratio of weight average molecular weight to number average molecular weight) and had an overall weight average molecular weight $(\mathrm{Mw})$ of $1.45 \times 10^{4} \mathrm{~g} \mathrm{moL}^{-1}$ and number average molecular weight $(\mathrm{Mn})$ of $5.7 \times 10^{3} \mathrm{~g} \mathrm{moL}^{-1}$. The molecular weight of MEPS from Bacillus sp.1-450 was $2.2 \times 10^{6} \mathrm{Da}$ and the functional groups in the molecular chains of the EPS are important determinants for biological activity (Kumar et al., 2004).

\section{Sub-Chronic Toxicity Study}

Owing to the extensive use of aluminum in treatment of drinking water and industrial purposes accidental and/ or prolonged exposure of both animals and human can lead to great economic losses in the animal wealth and toxicological hazards for human health. Heavy metal when consumed in considerable amount can result in damage or reduce mental and central nervous function, damage to blood composition, lung, kidneys, liver and other vital organs. Long term exposure may result in muscular and neurological disorder that mimic the AD, Parkinson's disease and muscular dystrophy (Shafii et al., 2011). The safety and toxicity information of herbal medicine or natural are required prior to expanded clinical studies and to support the registration of herbal and/or natural product with drug control agency. Sub-chronic toxicity study was carried out to observe any progressive effect of MEPS administration through the experimental period as compared to negative control rats and $\mathrm{AlCl}_{3}$-intoxicant rats. Administration of $\mathrm{AlCl}_{3}$ showed significant enlargement in heart $(0.42 \mathrm{~g} / 100 \mathrm{~g})$, liver $(3.75 \mathrm{~g} / 100 \mathrm{~g})$ and spleen $(0.39 \mathrm{~g} / 100 \mathrm{~g})$ as compared to control group $(0.37,3.10$ and $0.3 \mathrm{~g} / 100 \mathrm{~g}$, respectively) while other organs, lung, testis and brain were shrank $(0.50,0.57$ 
and $0.30 \mathrm{~g} / 100 \mathrm{~g}$, respectively) (Table 2). Administration of MEPS at $1 / 10$ of $\mathrm{LD}_{50}$ didn't produce any adverse effect on heart, lung, liver, kidney, testis or brain (Table 2), they remained near to controls. However, treating $\mathrm{AlCl}_{3}$-intoxicante animals for 90 days improved organs weight. It decreased the enlargement levels produced by $\mathrm{ALCl}_{3}$ intoxication $(0.38,3.31$ and $0.32 \mathrm{~g} / 100 \mathrm{~g}$ for heart, liver and spleen, respectively). These findings are compatible with those of recorded hematological parameters. $\mathrm{ALCl}_{3}$ administration produced significant increments in hemoglobin, PCV and white blood cell count also it was observed in augmentation of neutrophiles count, basophiles and eosinophiles. These increments were accompanied with significant decrease in red blood cell count, monocyte and eosinophiles (Table 3 ).

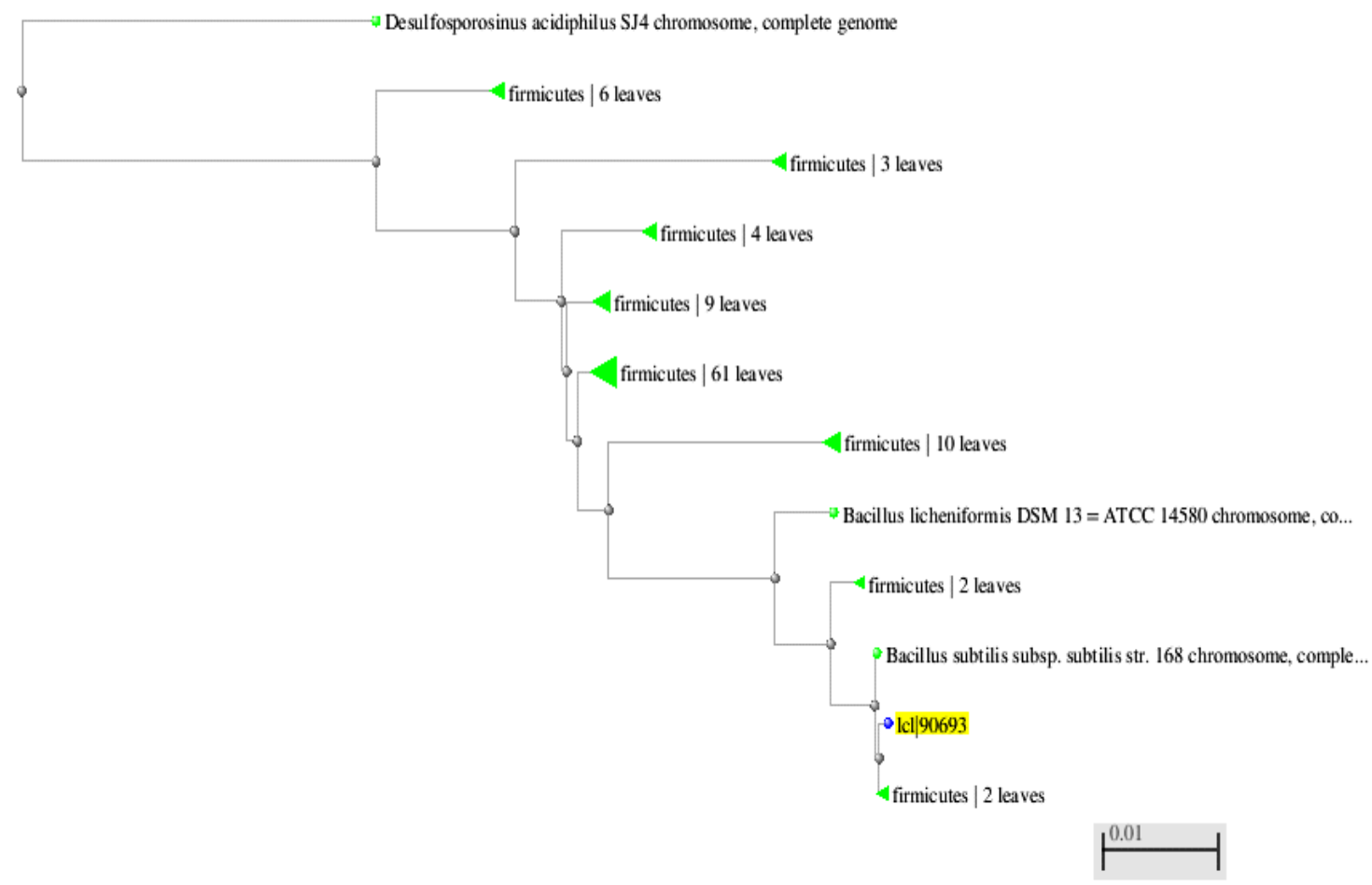

Fig. 1. Phylogenetic tree of the partial sequence of $16 \mathrm{~S}$ rDNA of the local isolate NRC27 with respect to closely related sequences available in GenBank databases

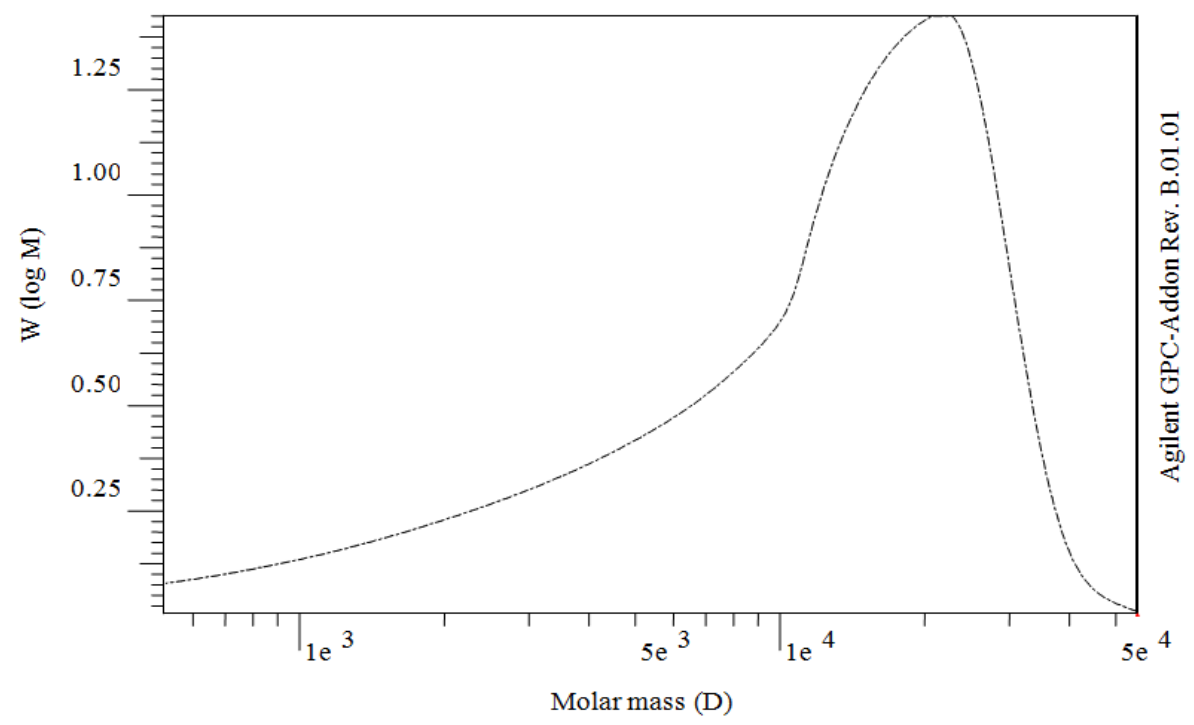

Fig. 2. Molecular weight distributions of MEPS production by Bacillus sp. M3 


\begin{tabular}{|c|c|c|c|c|c|c|c|}
\hline Group & Heart & Lung & Liver & Kidney & Spleen & Testis & Brain \\
\hline Control & $0.37 \pm 0.03^{\mathrm{b}}$ & $0.60 \pm 0.14^{\mathrm{c}}$ & $3.10 \pm 0.75^{\mathrm{d}}$ & $0.38 \pm 0.06^{\mathrm{f}}$ & $0.30 \pm 0.06^{\mathrm{g}}$ & $0.70 \pm 0.18^{h}$ & $1.00 \pm 0.12^{1}$ \\
\hline $\mathrm{ALCl}_{3}$ intoxicant & $0.42 \pm 0.01$ & $0.50 \pm 0.02$ & $3.75 \pm 0.95$ & $0.38 \pm 0.04^{\mathrm{f}}$ & $0.39 \pm 0.01$ & $0.57 \pm 0.03$ & $0.30 \pm 0.02$ \\
\hline MEPS group & $0.35 \pm 0.06^{\mathrm{b}}$ & $0.62 \pm 0.10^{\mathrm{c}}$ & $3.18 \pm 0.87^{\mathrm{d}}$ & $0.37 \pm 0.04^{\mathrm{f}}$ & $0.31 \pm 0.01^{\mathrm{g}}$ & $0.70 \pm 0.01^{\mathrm{h}}$ & $0.99 \pm 0.03^{\mathrm{I}}$ \\
\hline Treated intoxicant & $0.38 \pm 0.05^{\mathrm{b}}$ & $0.62 \pm 0.08^{\mathrm{c}}$ & $3.31 \pm 0.86$ & $0.37 \pm 0.06^{\mathrm{f}}$ & $0.32 \pm 0.05^{\mathrm{g}}$ & $0.69 \pm 0.02^{\mathrm{h}}$ & $0.75 \pm 0.01$ \\
\hline
\end{tabular}

Data are presented as mean of 15 animals \pm SD. Groups have the same letter have insignificant difference $\mathrm{p}<0.05$

Table 3. Effect of MEPS on hematological parameters in male rats

\begin{tabular}{|c|c|c|c|c|c|c|c|c|c|}
\hline \multirow[b]{2}{*}{ Group } & \multirow{2}{*}{$\begin{array}{l}\text { Hemoglobin } \\
\left(\mathrm{g} \mathrm{dL}^{-1}\right)\end{array}$} & \multirow[b]{2}{*}{$\begin{array}{l}\text { PCV } \\
(\mathrm{mm})\end{array}$} & \multirow{2}{*}{$\begin{array}{l}\text { RBC } \\
\left(\times 10^{3} / \mathrm{mm}^{3}\right)\end{array}$} & \multirow{2}{*}{$\begin{array}{l}\text { WBC } \\
\left(\times 10^{3} / \mathrm{mm}^{3}\right)\end{array}$} & \multicolumn{5}{|c|}{ Deferential white blood cell $(\%)$} \\
\hline & & & & & Monocyte & Eosinophile & Neutrophile & Lymphocyte & Basophile \\
\hline Control & $13.32 \pm 2.1$ & $39.87 \pm 3.14$ & $7.45 \pm 1.30^{b}$ & $9.65 \pm 0.99$ & $2.60 \pm 0.04$ & $1.60 \pm 0.03^{\mathrm{d}}$ & $22.09 \pm 1.40^{\mathrm{e}}$ & $72.01 \pm 2.85^{\mathrm{f}}$ & $1.70 \pm 0.01^{\mathrm{g}}$ \\
\hline $\mathrm{ALCl}_{3}$ intoxicant & $14.45 \pm 2.56^{\mathrm{a}}$ & $43.68 \pm 3.22$ & $6.20 \pm 1.11$ & $11.00 \pm 2.41$ & $1.71 \pm 0.08$ & $1.00 \pm 0.09$ & $42.42 \pm 3.11$ & $52.33 \pm 4.11$ & $2.68 \pm 0.08$ \\
\hline MEPS & $14.00 \pm 2.01^{\mathrm{a}}$ & $40.11 \pm 2.77$ & $7.65 \pm 1.64^{b}$ & $10.00 \pm 1.85^{\mathrm{c}}$ & $2.10 \pm 0.02$ & $1.54 \pm 0.04^{\mathrm{d}}$ & $23.00 \pm 2.64^{\mathrm{e}}$ & $71.67 \pm 3.52^{f}$ & $1.69 \pm 0.07^{\mathrm{g}}$ \\
\hline Treated intoxicant & $14.21 \pm 1.33^{\mathrm{a}}$ & $41.37 \pm 3.16$ & $7.20 \pm 1.05^{\mathrm{b}}$ & $10.22 \pm 2.10^{\mathrm{c}}$ & $1.92 \pm 0.01$ & $1.20 \pm 0.05$ & $30.72 \pm 3.01$ & $65.08 \pm 2.87$ & $1.08 \pm 0.03$ \\
\hline
\end{tabular}

Data are presented as mean of 15 animals \pm SD. Groups have the same letter have insignificant difference $p<0.05$

Data presented in Table 3 showed that administration of MEPS as positive control did not affect differential white blood cell with increasing of hemoglobin concentration while administration of aluminum chloride for 30 days increased white blood cell count $\left(11 \times 10^{3}\right.$ $\mathrm{mm}^{-3}$ ) that was observed in significant increment in neutrophiles with significant reduction in lymphocyte. As well as enhancing hemoglobin concentration (14.45 g $\mathrm{dL}^{-1}$ ) (Table 3). The ameliorative effect of MEPS administration for 90 days after aluminum intoxication was recorded. It reduce the increment level in PCV to be insignificant as compared to negative control (39.87 and $40.11 \mathrm{~mm}$ for treated and control groups, respectively) also increased the red blood cell count to reach the control group (7.20 and $7.45 \times 10^{6} \mathrm{~mm}^{-3}$, respectively) and saving the white blood count around the control group (10.22 and $9.65 \times 10^{3} \mathrm{~mm}^{-3}$ for treated and control, respectively) with plausible effect on differential count, it reduced the neutrophile production (30.72 and 42.42 for treated and intoxicant group, respectively) and induced lymphocyte production (65.08 and $52.33 \%$ for treated and intoxicant group, respectively) to rearrange the differentials count to reach nearly levels to control.

On the other hand, administration of aluminum chloride significantly increased AST and ALT activity (210.74 and $180.66 \mathrm{U} \mathrm{mL}^{-1}$, respectively) and protein and lipid production $\left(9.02 \mathrm{~g} \mathrm{dL}^{-1}\right.$ and $206.23 \mathrm{mg} \mathrm{dL}$, respectively) with augmentation of creatinine level, uric acid and urea concentration $\left(18.11 \mathrm{mg} \mathrm{dL}^{-1}, 3.02 \mathrm{mg}\right.$ $\mathrm{dL}^{-1}$ and $\left.5.15 \mathrm{mmol} \mathrm{L}^{-1}\right)$ as well as decreasing glutathione concentration $\left(0.88 \mathrm{mg} \mathrm{dL}^{-1}\right)$ (Table 4).

Polysaccharide administration didn't produce any progressive effect on all determined liver and kidney functions when animals treated for 90 days to serve as vehicle control group. On the other hand, it repaired the liver and kidney dysfunctions observed on AL-intoxicant animals. It reduced AST and ALT activities (156.24 and $100 \mathrm{U} \mathrm{mL}^{-1}$, respectively) and lipid peroxide production $\left(180.66 \mathrm{mg} \mathrm{dL}^{-1}\right)$ as well as elevation in glutathione from $0.88 \mathrm{mg} \mathrm{dL}^{-1}$ in intoxicant group to $2.11 \mathrm{mg} \mathrm{dL}^{-1}$ in treated intoxicant group. It also decreased creatinine production from 18.11 in intoxicant animal to $12.41 \mathrm{mg}$ $\mathrm{dL}^{-1}$ in treated intoxicated animals which accompanied with decreasing concentration of uric acid and urea from 3.02 and $5.15 \mathrm{mg} \mathrm{dL}^{-1}$ in intoxicated rats, respectively, to 2.10 and $3.25 \mathrm{mg} \mathrm{dL}^{-1}$ in treated group. Generally, administration of polysaccharide after aluminum toxicity ameliorated all determined liver and kidney functions as a part of sub-chronic toxicity study.

Our data are in accordance with those of Sallam et al. (2005) who reported that treatment with $\mathrm{AlCl}_{3}$ resulted in significant decrease in body weight, feed intake, drinking water, nitrogen balance, digestibility coefficients. Also, treatment had significant effects on the activities of Aspartate Aminotransferase (AST), Alanine Amino Transferase (ALT), Alkaline Phosphatase (AlP), Acid Phosphatase (AcP) and the concentration of Thiobarbituric Acid-Reactive Substances (TBARS) plasma enzymes activity.

\section{Anti-Alzheimer Effect of MEPS on Male Rats}

Oxidative stress parameters were decreased by MEPS administration as vehicle group. It reduced production of malondialdehyde (3.61 nmol mg-1 protein), hydrogen peroxide (3.61 nmol mg $\mathrm{m}^{-1}$ protein) and nitric oxide (1.11 $\mu \mathrm{mo} \mathrm{lmg}^{-1}$ protein) also it stimulated antioxidant parameters as catalase activity $\left(6.99 \mathrm{U} \mathrm{mg}^{-1}\right.$ protein), superoxide dismutase $\left(4.38 \mathrm{U} \mathrm{mg}^{-1}\right.$ protein) and total antioxidant capacity (14.99 $\mathrm{mmol} \mathrm{mg}^{-1}$ protein) determined in brain tissue while aluminum chloride adminis tration enhance all oxidative stress parameters. It augmented production of malonedialdehyde (11.26 $\mathrm{nmolmg}^{-1}$ protein) and hydrogen peroxide $(10.41 \mathrm{nmol}$ $\mathrm{mg}^{-1}$ protein) and nitric oxide conc. $\left(9.23 \mu \mathrm{molmg}^{-1}\right.$ protein) as well as depression in catalase activity $(3.26 \mathrm{U}$ $\mathrm{mg}^{-1}$ protein) and SOD activity $\left(2.81 \mathrm{U} \mathrm{mg}^{-1}\right.$ protein) which highly lowered total antioxidant capacity (6.48 $\mathrm{mmolmg}^{-1}$ protein) (Table 5). When intoxicant animals treated with MEPS, it inhibited the production of oxidative stress molecules in cells, therefore malon- 
dialdehyde were decreased to reach $5.99 \mathrm{nmol} \mathrm{mg}^{-1}$ protein, hydrogen peroxide to be $5.13 \mathrm{nmol} \mathrm{mg}^{-1}$ protein

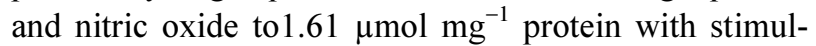
ation of antioxidant parameters. The MEPS enhanced the activity of catalase $\left(5.46 \mathrm{U} \mathrm{mg}^{-1}\right.$ protein) and SOD (3.77 $\mathrm{U} \mathrm{mg}^{-1}$ protein) with amelioration in total antioxidant capacity (10.58 mmol mg $\mathrm{mg}^{-1}$ protein). Tissue damage resulting from an imbalance between reactive oxygen species generating and scavenging systems (oxidative stress) has been implicated in the pathogenesis of a variety of disorders, including dege-nerative disorders of the CNS such as Alzheimer's disease (Harman, 1993).

Animals intoxicated with aluminum chloride have high acetyl cholinesterase activity (915.34 $\mathrm{U} \mathrm{mg}^{-1}$ protein) with low acetylcholine concentration $\left(5.76 \times 10^{-2}\right.$ mmol $\mathrm{mg}^{-1}$ protein) with elevation in calcium binding

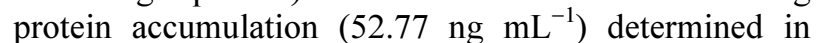
these animals sera. On the other hand, oral administration of polysaccharide showed inhibitory effect on acetyl cholinesterase activity (306.21 $\mathrm{U} \mathrm{mg}^{-1}$ protein) which increased acetylcholine concentration in brain cell $\left(8.87 \times 10^{-2} \mathrm{mmol} \mathrm{mg}^{-1}\right.$ protein) with reduction calcium binding protein accumulation in serum $\left(23.43 \mathrm{ng} \mathrm{mL}^{-1}\right)$ (Table 6). Treating intoxicant animals with polysaccharide showed positive effect on acetylcholine biomarkers. It inhibited acetyl cholinesterase activity
(510.55 $\mathrm{U} \mathrm{mg}^{-1}$ protein) that increases accumulation of acetylcholine in brain cells $\left(7.36 \times 10^{-2} \mathrm{nmol} \mathrm{mg}^{-1}\right.$ protein). This plausible effect was accompanied with decreasing in Ca-binding protein concentration $33.92 \mathrm{ng}$ $\mathrm{mL}^{-1}$. The bioactivities of polysaccharides can be affected by many factors including chemical comp-onents, molecular weight, configuration and isolation methods (Xu et al., 2011). The research on chemical characterization and antioxidant properties of polysacch-arides from Sargassum fusiforme found that a relatively low molecular weight and a relatively high uronic acid content could increase the antioxidant activity (Zhou et al., 2008). Likewise, it had been reported that there was a direct relationship between the uronic acid contents and the radical scavenging effects of tea polysaccharide conjugates (Chen et al., 2004; 2008).

Inhibition of Acetyl Cholinesterase (AChE), the key enzyme in the breakdown of Acetylcholine (ACh), is considered as a promising strategy for the treatment of neurological disorders such as $\mathrm{AD}$, senile dementia, ataxia and myasthenia gravis. Principal role of AChE is the termination of nerve impulse transmission at the cholinergic synapses by rapid hydrolysis of ACh. Inhibition of AChE serves as a strategy for the treatment of $\mathrm{AD}$, senile dementia, ataxia, myasthenia gravis and Parkinson's disease (Rahman and Choudhary, 2001).

Table 4. Liver and kidney functions of rats administered MEPS for 90 days

\begin{tabular}{|c|c|c|c|c|c|c|c|c|}
\hline Group & $\begin{array}{l}\text { AST } \\
\left(\mathrm{U} \mathrm{mL}^{-1}\right)\end{array}$ & $\begin{array}{l}\text { ALT } \\
\left(\mathrm{U} \mathrm{mL}^{-1}\right)\end{array}$ & $\begin{array}{l}\text { Protein } \\
\left(\mathrm{g} \mathrm{dL}^{-1}\right)\end{array}$ & $\begin{array}{l}\text { Total lipid } \\
\left(\mathrm{mg} \mathrm{dL}^{-1}\right)\end{array}$ & $\begin{array}{l}\text { Glutathione } \\
\left(\mathrm{mg} \mathrm{dL}^{-1}\right)\end{array}$ & $\begin{array}{r}\text { Creatinine } \\
\left(\mathrm{mg} \mathrm{dL}^{-1}\right)\end{array}$ & $\begin{array}{l}\text { Uric acid } \\
\left(\mathrm{mg} \mathrm{dL}^{-1}\right)\end{array}$ & $\begin{array}{l}\text { Urea } \\
\left(\mathrm{mmol} \mathrm{L}^{-1}\right)\end{array}$ \\
\hline Control & $100.56 \pm 2.44$ & $79.20 \pm 2.83$ & $7.23 \pm 0.29$ & $154.40 \pm 3.11$ & $3.74 \pm 0.43$ & $09.34 \pm 0.56$ & $1.68 \pm 0.15$ & $2.23 \pm 0.83$ \\
\hline $\mathrm{ALCl}_{3}$ intoxicant & $210.74 \pm 3.01^{\mathrm{a}}$ & $180.66 \pm 4.67^{\mathrm{a}}$ & $9.02 \pm 1.06^{\mathrm{a}}$ & $206.23 \pm 2.94^{\mathrm{a}}$ & $0.88 \pm 0.08^{\mathrm{a}}$ & $18.11 \pm 1.13^{\mathrm{a}}$ & $3.02 \pm 0.24^{\mathrm{a}}$ & $5.15 \pm 0.09^{\mathrm{a}}$ \\
\hline MEPS & $106.00 \pm 2.87$ & $82.33 \pm 3.01$ & $7.31 \pm 1.02$ & $160.18 \pm 2.54$ & $4.12 \pm 0.19^{\mathrm{a}}$ & $09.02 \pm 1.02$ & $1.59 \pm 0.28$ & $2.21 \pm 0.07$ \\
\hline Treated intoxicant & $156.24 \pm 1.0^{\mathrm{ab}}$ & $100.00 \pm 1.02^{\mathrm{ab}}$ & $8.14 \pm 1.10^{\mathrm{ab}}$ & $180.06 \pm 3.06^{\mathrm{ab}}$ & $2.11 \pm 0.04^{\mathrm{ab}}$ & $12.41 \pm 2.06^{\mathrm{ab}}$ & $2.10 \pm 0.11^{\mathrm{ab}}$ & $3.25 \pm 0.13^{\mathrm{ab}}$ \\
\hline
\end{tabular}

Data are presented as mean of 15 replicates \pm SD

a; significant change at $\mathrm{p}<0.05$ for control group

b; significant with Al-intoxicant control group

Table 5. Effect of MEPS on brain oxidative stress biomarkers and brain antioxidant status in normal and AL-intoxicant groups

\begin{tabular}{|c|c|c|c|c|c|c|}
\hline Groups & $\begin{array}{l}\text { MDA } \\
\left(\mathrm{nmol} \mathrm{mg}^{-1}\right)\end{array}$ & $\begin{array}{l}\mathrm{H}_{2} \mathrm{O}_{2} \\
\left(\mathrm{nmol} \mathrm{mg}^{-1}\right)\end{array}$ & $\begin{array}{l}\mathrm{NO}_{2} \\
\left(\mu \mathrm{mol} \mathrm{mg}{ }^{-1}\right)\end{array}$ & $\begin{array}{l}\text { CAT } \\
\left(\mathrm{U} \mathrm{mg}^{-1}\right)\end{array}$ & $\begin{array}{l}\text { SOD } \\
\left(\mathrm{U} \mathrm{mg}^{-1}\right)\end{array}$ & $\begin{array}{l}\text { T-AOC } \\
\left(\mathrm{mmol} \mathrm{mg}^{-1}\right)\end{array}$ \\
\hline Control & $04.11 \pm 1.37$ & $04.86 \pm 1.61$ & $1.91 \pm 1.13$ & $5.46 \pm 0.65$ & $3.11 \pm 0.91$ & $12.46 \pm 1.22$ \\
\hline $\mathrm{AlCl}_{3}$-intoxicant & $11.26 \pm 2.63^{\mathrm{a}}$ & $10.41 \pm 1.97^{\mathrm{a}}$ & $9.23 \pm 1.52^{\mathrm{a}}$ & $3.26 \pm 2.11^{\mathrm{a}}$ & $2.81 \pm 0.99^{\mathrm{a}}$ & $06.48 \pm 1.94^{\mathrm{a}}$ \\
\hline MEPS & $03.61 \pm 0.91^{\mathrm{a}}$ & $3.42 \pm 1.42^{\mathrm{a}}$ & $1.11 \pm 0.86^{\mathrm{a}}$ & $6.99 \pm 1.04^{\mathrm{a}}$ & $4.38 \pm 0.79^{\mathrm{a}}$ & $14.99 \pm 0.05^{\mathrm{a}}$ \\
\hline Treated intoxicant & $05.99 \pm 1.94^{\mathrm{ab}}$ & $5.13 \pm 1.18^{\mathrm{ab}}$ & $1.61 \pm 0.31^{\mathrm{ab}}$ & $5.46 \pm 0.97^{\mathrm{ab}}$ & $3.77 \pm 0.81^{\mathrm{ab}}$ & $10.58 \pm 1.23^{\mathrm{ab}}$ \\
\hline
\end{tabular}

Data are presented as mean of 15 replicates \pm SD

a; significant change at $\mathrm{p}<0.05$ for control group

b; significant with Al-intoxicant control group

Table 6. Effect of MEPS on Ca binding protein and acetylcholine biomarkers

\begin{tabular}{llll}
\hline Groups & Ach $\left(\mathrm{nmol} \mathrm{mg}^{-1}\right)$ & AChE $\left(\mathrm{U} \mathrm{mg}^{-1}\right)$ & $\mathrm{S} 100 \mathrm{~B}\left(\mathrm{ng} \mathrm{mL} \mathrm{m}^{-1}\right)$ \\
\hline Control & $7.69 \times 10^{-2} \pm 3.11$ & $498.56 \pm 2.27$ & $24.75 \pm 1.01$ \\
$\mathrm{AlCl}_{3}$ - intoxicant & $5.76 \times 10^{-2} \pm 1.53^{\mathrm{a}}$ & $915.34 \pm 3.41^{\mathrm{a}}$ & $52.77 \pm 3.21^{\mathrm{a}}$ \\
MEPS & $8.87 \times 10^{-2} \pm 2.43^{\mathrm{a}}$ & $306.21 \pm 2.38^{\mathrm{a}}$ & $23.43 \pm 2.42$ \\
Treated intoxicant & $8.26 \times 10^{-2} \pm 1.76^{\mathrm{b}}$ & $510.55 \pm 2.15^{\mathrm{ab}}$ & $33.92 \pm 3.16^{\mathrm{ab}}$ \\
\hline
\end{tabular}

Data are presented as mean of 15 replicates \pm SD

a; significant change at $\mathrm{p}<0.05$ for control group

$\mathrm{b}$; significant with $\mathrm{Al}$-intoxicant control group 
There are a few synthetic medicines, e.g., tacrine, donepezil and the natural product-based rivastigmine for treatment of cognitive dysfunction and memory loss associated with AD (Oh et al., 2004). These compounds have been reported to have their adverse effects including gastrointestinal disturbances and problems associated with bioavailability (Schulz, 2003) which necessitates the interest in finding better AChE inhibitors from natural resources. The EPS attenuated the LPS-induced release of pro-inflammatory factors possibly via suppressing the activation of NF-kB and ASK1-p38/JNK signaling and reduced the LPS-induced intracellular ROS accumulation which may possibly at least in part contribute to the suppression of NF-kB and ASK1-p8/JNK and then to the reduced productions of pro-inflammatory cytokines (Diao et al., 2014). Generally, MEPS showed potent anti-Alzheimer effect as well as it didn't have any chronic toxicity through the experim-ental period. These findings suggest that polysaccharide isolated from Bacillus sp. M3 may be a good natural source for Alzheimer disease therapy.

\section{Conclusion}

The water soluble exopolysaccharide coded as MEPS isolated from a newly Bacillus sp. M3 contained galacturonic acid and glucuronic acid with molecular masse of $1.45 \times 10^{4} \mathrm{~g} / \mathrm{mol}$. FT-IR, UV-Vis spectral analyses revealed prevalence of characteristic primary belonged to $\alpha$-type with a pyranose ring. The MEPS ameliorated antioxidant status and reduced all oxidative stress parameters in brain tissue with decreasing S100B as compared to aluminum toxicant group with significant acetyl cholinesterase inhibition which increase acetyl choline concentration in brain tissue.

\section{Acknowledgement}

The authors extend their appreciation to the National Research Centre, Egypt for funding this work as a part of National Research Centre activities.

\section{Funding Information}

This work was performed and funded as a part of National Research Centre plan to support the use of natural sources in treating diseases.

\section{Author's Contributions}

MMSA, MGM and SSM designed the study. Isolation, screening, identification of bacterial strain and MEPS was prepared by bacteria. Chemical charact erization of MEPS was carried by MMSA and MGM. Animal study experiments were carried out by AYI. The data were analyzed by MMSA, MGM, AYI and SSM. The manuscript was written by MMSA with contributions from MGM and AYI.

\section{Ethics}

This study was approved by Medical Research Ethics Committee, National Research Centre, Egypt, under registration no. 11015 .

\section{References}

Anonymous, 1965. Recommendations and requirements for hemoglobinometry in human blood. J. Clin. Pathol., 18: 335-338.

Asker, M.M.S., Y.M. Ahmed and M.F. Ramadan, 2009. Chemical characteristics and antioxidant activity of exopolysaccharide fractions from Microbacterium terregens. Carbohydrate Polymers, 77: 563-567. DOI: 10.1016/j.carbpol.2009.01.037

Balkwill, F.R. and A. Mantovani, 2012. Cancer-related inflammation: Common themes and therapeutic opportunities. Seminars Cancer Biol., 22: 33-40. DOI: 10.1016/j.semcancer.2011.12.005

Beers, R.F. and I.W. Sizer, 1952. A spectrophotometric method for measuring the breakdown of hydrogen peroxide by catalase. J. Biol. Chem., 195: 133-140. PMID: 14938361

Bremer, P.J. and G.G. Geesey, 1991. An evaluation of biofilm development utilizing non-destructive attenuated total reflectance Fourier transform infrared spectroscopy. Biofouling, 3: 89-100. DOI: $10.1080 / 08927019109378165$

Bruce, R.D., 1985. An up-and-down procedure for acute toxicity testing. Fundamental Applied Toxicol., 5: 151-157. DOI: 10.1016/0272-0590(85)90059-4

Calazans, G.M.T., C.E. Lopes, R.M.O.C. Lima and F.P. de Franc, 1997. Antitumour activities of levans produced by Zymomonas mobilis strains. Biotech-nol. Letter, 19: 19-21. DOI: 10.1023/A:1018350617120

Carolina, A.A., D. Oliveira, V.C. Assis, M. Auxiliadora and C. Matos et al., 2005. Flow-injection system with glucose oxidase immobilized on a tubular reactor for determination of glucose in blood samples. Analytical Chim. Acta., 535: 213-217. DOI: $10.1016 /$ j.aca.2004.11.053

Chen, H.X., M. Zhang, Z.S. Qu and B.J. Xie, 2008. Antioxidant activities of different fractions of polysaccharide conjugates from green tea (Camellia Sinensis). Food Chem., 106: 559-563.

DOI: 10.10 16/j.foodchem.2007.06.040

Chen, H.X., M. Zhang and B.J. Xie, 2004. Quantification of uronic acids in tea polysaccharide conjugates and their antioxidant properties. J. Agric. Food Chem., 52: 3333-3336. DOI: 10.1021/jf03496 79

Cheng, A., F. Wan, Z. Jin, J. Wang and X. Xu, 2008. Nitrite oxide and inducible nitric oxide synthase were regulated by polysaccharides isolated from Glycyrrhiza uralensis Fisch. J. Ethnopharmacol., 118: 59-64. DOI: 10.1016/j.jep.2008.03.002 
Christensen, B.E., J. Kjosbakken and O. Smidsrod, 1985. Partial chemical and physical characterization of two extracellular polysaccharides produced by marine, periphytic pseudomonas sp. strain NCMB 2021. Applied Environ. Microbiol., 50: 837-845.

Cummings, J.L., 2004. Alzheimer's disease. N Eng. J. Med., 351: 56-67. DOI: 10.1056/NEJMra040223

Czaczyk, K. and K. Myszka, 2007. Biosynthesis of Extracellular Polymeric Substances (EPS) and its role in microbial biofilm formation. J. Environ Stud., 16: 799-806.

Dacie, J.V. and S.M. Lewis, 1975. Laboratory Investigation in Hemolytic Anemia in Practical Haematology, 5th Edn., Churchil Livingstone, pp: 40.

Decho, A., 1990. Microbial exopolymer secretions in ocean environments: Their role(s) in food webs and marine processes. Oceanogr. Mar. Biol. Annu. Rev., 28: 73-154.

Demirovic, J.A., A.B. Pai and M.P. Pai, 2009. Estimation of creatinine clearance in morbidly obese patients. Am. J. Health Syst. Pharm., 66: 642-648. DOI: 10.2146/ajhp080200

Diao, Y., Y. Xin, Y. Zhou, N. Li and X. Pan et al., 2014. Extracellular polysaccharide from Bacillus sp. strain LBP32 prevents LPS-induced inflammation in RAW 264.7 macrophages by inhibiting NF- $\kappa \mathrm{B}$ and MAPKs activation and ROS production. Int. Immunopharmacol., 18: 12-19. DOI: $10.1016 /$ j. intimp.2013.10.021

Dubois, M., K.A. Gilles, J.K. Hamilton, P.A. Rebers and F. Smith, 1956. Colorimetric method for determination of sugars and related substances. Analytical Chem., 28: 350-356. DOI: 10.1021/ac60111a017

El-Sayed, O.H., S.A. Ismail, Y.M. Ahmed, M. Abd El-Samei and M.M.S. Asker, 2005. Studies on the production of sulfated polysaccharide by locally isolated bacteria. Egyptian Pharmaceutical J., 4: 439-452.

Emanuele, E., V. Martinelli, M. Carlin, V. Fugazza and E. Barale et al., 2011. Serum levels of soluble Receptor for Advanced Glycation Endproducts (sRAGE) in patients with different psychiatric disorders. Neurosci. Letter, 487: 99-102.

DOI: 10.1016/j.neulet.2010.10.003

Gao, F., D.N.F. Harris and S. Sapsed-Byrne, 1997. Neurone-specific enolase and Sangtec 100 assays during cardiac surgery: Part I-the effects of heparin, protamine and propofol. Perfusion, 12: 163-165. DOI: $10.1177 / 026765919701200303$

Gardes, M. and T.D. Bruns, 1993. ITS primers with enhanced specificity for basidiomycetes-application to the identification of mycorrhizae and rusts. Molecular Ecol., 2: 113-118. DOI: $10.1111 /$ j.1365-294X.1993.tb00005.x

Ghai, C.L., 1995. Haematological Studies. In: A Textbook of Practical Physiology, Ghai, C.L., (Ed.), Jaypee Brother's Medical Publisher, India, pp: 136-162.
Griffith, O., 1980. Determination of glutathione and glutathione disulfide using glutathione reductase and 2-vinylpyridine. Analytical Biochem., 106: 207-212. DOI: 10.1016/0003-2697(80)90139-6

Guo, S.D., W.J. Mao and Y. Han, 2010. Structural characteristics and antioxidant activities of the extracellular polysaccharides produced by marine bacterium Edwardsiella tarda. Bioresource Technol., 101: 4729-4732.

DOI: 10.1016/j.biortech. 2010.01.125

Gutierrez, R.M., A.M. Gonzalez and A.M. Ramirez, 2012. Compounds derived from endophytes: A review of phytochemistry and pharmacology. Curr. Med. Chem., 19: 2992-3030.

DOI: $10.2174 / 092986712800672111$

Hannig, C., B. Spitzmuller and M. Hannig, 2009. Transaminases in the acquired pellicle. Arch. Oral Biol., 54: 445-448.

DOI: $10.1016 /$ j.archoralbio. 2009.02.005

Harman, D., 1993. Free radical theory of aging: A hypothesis on pathogenesis of senile dementia of the Alzheimer's type. AGE, 16: 23-30. DOI: $10.1007 /$ BF02436127

Holmstrom, C. and S. Kjelleberg, 1999. Marine Pseudoalteromonas species are associated with higher organisms and produce biologically active extracellular agents. FEMS Microbiol. Ecol., 30: 285-293. DOI: 10.1111/j.1574-6941.1999.tb00656.x

Holt, J.G., 1986. Bergey's Manual of Systematic Bacteriology. 1st Edn., Williams and Wilkins, Baltimore U.A., ISBN-10: 0683078933, pp: 2648.

Inmaculada, L., A.M. Juan, T. Richard, B. Philippe and C. María et al., 2010. Characterization of the exopolysaccharide produced by salipiger mucosus $\mathrm{A} 3^{\mathrm{T}}$, a halophilic species belonging to the alphaproteobacteria, isolated on the Spanish Mediterranean seaboard. Mar Drugs, 8: 2240-2251. DOI: $10.3390 / \mathrm{md} 8082240$

Jun, L., L. Jiangguang, Y. Hong, S. Yi and L. Zhaoxin et al., 2009. Production, characterization and anti-oxidant activities in vitro of exopolysaccharides from endophytic bacterium paenibacillus polymyxa EJS-3. Carbohydrate Polymers, 78: 275-281.

DOI: $10.1016 /$ j.carbpol.2009.03.046

Kakkar, P., B. Das and P. Viswanathan, 1984. A modified spectrophotometric assay of superoxide dismutase. Ind. J. Biochem. Biophys., 21: 130-132. PMID: 6490072

Kanmani, P., R.S. Kumar, N. Yuvaraj, K.A. Parri and V. Pattukumar et al., 2011. Production and purification of a novel exopolysaccharide from lactic acid bacterium Streptococcus phocae PI80 and its functional characteristics activity in vitro. Bioresource Technol., 102: 4827-4833. DOI: 10.1016/j.biortech.2010.12.118 
Kim, S., S. Ahu, W. Seo, G. Kwan and Y. Park, 1998. Rheological properties of a novel high viscosity polysaccharide, A49-Pol, produced by Bacillus polymyxa. J. Microb. Biotechnol., 8: 178-181.

Koracevic, D., G. Koracevic, V. Djordjevic, S. Andrejevic and V. Cosic, 2001. Method for the measurement of antioxidant activity in human fluids. J. Clin. Pathol., 54: 356-361.

DOI: $10.1136 /$ jcp.54.5.356

Krasovskii, G.N., L.Y. Vasukovich and O.G. Chariev, 1979. Experimental study of biological effects of lead and aluminum following oral administration. Environ. Health Perspect., 30: 47-51. DOI: $10.2307 / 3429101$

Kumar, C.G., J. Han-Seung, C. Jang-Won, K. YoonMoo and C. Chung-Soon, 2004. Purification and characterization of an extracellular polysaccharide from haloalkalophilic Bacillus sp. I-450. Enzyme Microbial Technol., 34: 7673-681.

DOI: 10.10 16/j.enzmictec.2004.03.001

Llamas, I., J.A. Mata, R. Tallon, P. Bressollier and M.C. Urdaci et al., 2010. Characterization of the exopolysaccharide produced by salipiger mucosus $\mathrm{A}^{\mathrm{T}}$, a halophilic species belonging to the alphaproteobacteria, Isolated on the Spanish Mediterranean Seaboard. Marine Drugs, 8: 2240-2251. DOI: $10.3390 / \mathrm{md} 8082240$

Luo, D. and B. Fang, 2008. Structural identification of ginseng polysaccharides and testing of their antioxidant activities. Carbohydrate Polymers, 72: 376-381. DOI: 10.1016/j.carbpol.2007.09.006

Mahmoud. M.G., A.Y. Ibrahim, M.M.S. Asker and O.H. El Sayed, 2014. Therapeutic potential and structural elucidation of a water-soluble polysaccharide of a wild edible mushroom Agaricus bisporus against neurodegenerative disease, Alzheimer World. J. Pharm. Sci., 2: 1136-1145.

Mark, R.E. and W.ST. Griffin, 2001. The role of activated astrocytes and of the neurotrophic cytokine S100B in the pathogenesis of Alzheimer's disease. Neurobiol. Aging, 22: 915-922.

DOI: $10.1016 / \mathrm{S} 0$ 197-4580(01)00293-7

Montgomery, H.A.C. and J.F. Dymock, 1961. The determination of nitrite in water. Analyst., 86: 414-416.

Nelson, V.M., C.M. Dancik, W. Pan, Z.G. Jiang and M.S. Lebowitz et al., 2009. PAN-811 inhibits oxidative stress-induced cell death of human Alzheimer's disease-derived and age-matched olfactory neuroepithelial cells via suppression of intracellular reactive oxygen species. J. Alzheimer's Disease, 17: 611-619. PMID: 19433896

Oh, M.H., P.J. Houghton, W.K. Whang and J.H. Cho, 2004. Screening of Korean herbal medicines used to improve cognitive function for anti-cholinesterase activity. Phytomedicine, 11: 544-548.

DOI: $10.1016 /$ j.phymed.2004.03.001
Ohkawa, H., N. Ohishi and K. Yagi, 1979. Assay for lipid peroxides in animal tissues by thiobarbituric acid reaction. Analytical Biochem., 95: 351-358. DOI: 10.1016/0003-2697(79)90738-3

Okutucu, B., A. Dincer, A. Habib and F. Zihnıoglu, 2007. Comparison of five methods for determination of total plasma protein concentration. J. Biochem. Biophys. Meth., 70: 709-711. DOI: 10.1016/j.jbbm.2007.05.009

Parthiban, K., V. Vignesh and R. Thirumurugan, 2014. Isolation and Characterization of exopolysaccharide producing bacteria from pak bay (mandapam). Int. J. Oceanography Marine Ecological Syst., 3: 1-8. DOI: 10.3923/ijomes.2014.1.8

Plancarte, A. and G.M. Hernandez, 2004. Purification, characterization and kinetic properties of the multifunctional thioredoxin-glutathione reductase from Taenia crassiceps metacestode (Cysticerci). Molec. Biochem. Parasitol., 133: 61-69. DOI: 10.10 16/j.molbiopara.2003.09.003

Rahman, A.U. and M.I. Choudhary, 2001. Bioactive natural products as a potential source of new pharmacophores. A theory of memory. Pure. Appl. Chem., 73: 555-560.

Ray, B., 2006. Polysaccharides from Enteromorpha compressa: Isolation, purification and structural features. Carbohydrate Polymers, 66: 408-416. DOI: 10.1016/j.carbpol.2006.03.027

Sallam, S.M.A., M.E.A. Nasser, M.S.H. Yousef, A.M. El-morsy and S.A.S. Mahmoud et al., 2005. Influence of aluminum chloride and ascorbic acid on performance, digestibility, caecal microbial activity and biochemical parameters of rabbits. Res. J. Agric. Biological Sci., 1: 10-16.

Schacter, E. and S.A. Weitzman, 2002. Chronic inflammation and cancer. Oncology, 16: 217-232.

Schulz, V., 2003. Ginkgo extract or cholinesterase inhibitors in patients with dementia: What clinical trials and guidelines fail to consider. Phytomedicine, 10: 74-79. DOI: 10.1078/1433-187X-00302

Sedlack, J. and R.H. Lindsay, 1968. Estimation of total, protein-bound and nonprotein sulfhydryl groups in tissue with Ellman's reagent. Analytical Biochem., 25: 192-205. DOI: 10.1016/0003-2697(68)90092-4

Shafii, K., M.S. Fazliana and A.R. Shamsiah, 2011. Preliminary toxicological evaluation and heavy metal determination of selected Malaysian medicinal plants. Health Environ. J., 2: 6-8.

Sudhamani, S.R., R.N. Tharanathan and M.S. Prasad, 2004. Isolation and characterization of an extracellular polysaccharide from Pseudomonas caryophylli CFR 1705. Carbohydrate Polymers, 56: 423-427. DOI: 10.1016/j.carbpol.2004.03.008

Sun, R.C., J.M. Fang, A. Goodwin, J.M. Lawther and A.J. Bolton, 1998. Fractionation and characterization of polysaccharides from abaca fibre. Carbohydrate Polymers, 37: 351-359. DOI: 10.1016/S0144-8617(98)00046-0 
Tamura, K., D. Peterson, N. Peterson, G. Stecher and M. Nei et al., 2011. MEGA 5 : Molecular evolutionary genetics analysis using maximum likelihood, evolutionary distance and maximum parsimony methods. Molecular Biol. Evolut., 28: 2731-2739. DOI: $10.1093 / \mathrm{molbev} / \mathrm{msr} 121$

Tong, H., F. Xia, K. Feng, G. Sun and X. Gao, 2009. Structural characterization and in vitro antitumor activity of a novel polysaccharide isolated from the fruiting bodies of Pleurotus ostreatus. Bioresource Technol., 100: 1682-1686. DOI: 10.1016/j.biortech. 2008.09.004

Upadhyaya, P., S. Vikas and A. Mushtaq, 2010. Therapy of Alzheimer's disease: An update. Afr. J. Pharmacy Pharmacol., 4: 408-421.

Vatassery, G.T., M.A. Sheridan, A.M. Krezowski, A.S. Divine and H.L. Bach, 1981. Use of the sulfophospo-vanillin reaction in a routine method for determining total lipids in human cerebrospinal fluid. Clin. Biochem., 14: 21-24.

DOI: $10.1016 / 0009-9120(81) 90120-\mathrm{X}$

Wang, H., E.V. Ooi and P.O. Ang, 2007. Antiviral polysaccharides isolated from Hong Kong brown seaweed Hydroclathrus clathratus. Sci. China, 50: 611-618. DOI: 10.1007/s11427-007-0086-1

$\mathrm{Xu}$, R.H., Q. Shen, X.L. Ding, W.G. Gao and P.L. Li, 2011. Chemical characterization and antioxidant activity of an exopolysaccharide fraction isolated from Bifidobacterium animalis RH. Eur. Food Res. Technol., 232: 231-241.

DOI: $10.1007 / \mathrm{s} 00217-010-1382-8$
Xu, W., F. Zhang, Y. Luo, L. Ma and X. Kou et al., 2009. Antioxidant activity of a water-soluble polysaccharide purified from Pteridium aquilinum. Carbohydrate Res., 344: 217-222.

DOI: $10.1016 /$ j.carres.2008.10.021

Yoneyame, K., Y. Fujino, T. Osaka and I. Satoh, 2001. Amperometric sensing system for the detection of urea by a combination of the $\mathrm{pH}$-stat method and flow injection analysis. Sens Acutat., 76: 152-157. DOI: 10.1016/S0925-4005(01)00613-X

You, L., G. Qing, F. Mengying, Y. Bao and R. Jiaoyan et al., 2013. Structural characterisation of polysaccharides from Tricholoma matsutake and their antioxidant and antitumour activities. Food Chem., 138: 2242-2249.

DOI: $10.1016 /$ j.food chem.2012.11.140

Zhou, J., N. Hu, Y.L. Wu, Y.J. Pan and C.R. Sun, 2008. Preliminary studies on the chemical characterization and antioxidant properties of acidic polysaccharides from Sargassum fusiforme. J. Zhejiang Univ. Sci. B, 9: 721-727. DOI: 10.1631 jzus.B0820025 